\title{
HIGHER EDUCATION WRITING STUDIES IN LATIN AMERICA
}

\author{
Charles Bazerman \\ University of California Santa Barbara \\ Santa Barbara, US \\ Maria Ester W. Moritz \\ Federal University of Santa Catarina \\ Florianópolis, Santa Catarina, BR
}

Many universities across Central and South America in the last fifteen years have begun to pay more concerted attention to the writing of students and faculty. While this work grows from some earlier beginnings, it is only recently that a critical mass of faculty and researchers across universities and across countries have recognized their common cause and begun to share work and build networks for mutual support.

Acting on this common concern for improving academic writing in both first and and additional languages has had to overcome many obstacles, not least of which is finding a place in the university to support writing, as in most countries in the region there was no department that saw developing student writing as a major charge and there were few curricular structures that gave place to the teaching of writing. So new institutions such as writing centers had to be created, or new courses added into degree requirements, or courses in other subjects needed to add more explicit and intentional writing components, perhaps in collaboration with language or writing experts.

This lack of a clear academic home for writing instruction and research has also meant that researchers and teachers were located in different departments, producing research from different perspectives and bringing different approaches to instruction. Further, research and teaching specialists had few professional forums where they could meet and discuss their common work. This thematic issue of Ilha do Desterro documents, exhibits, and carries forward the desire to understand and improve academic writing at the university level. This issue is in fact a forum that brings together writing researchers in the region to share what they have found out about the kinds of writing that students and faculty do, the writing environment and perception on the their campuses and in their regions, and their interventions and programs to improve academic writing. Several articles also provide synoptic overviews of the development of writing specialists. The issue also includes a number of multi-book reviews to indicate the kind of scholarship developing in other publications.

The largest group of articles use research to build understanding of the writing environment and expectations on different campuses and of the writing actually being done by students.

Two articles report research using online platforms as the locus for academic writing practices. Franco and Castanheira's article examines academic literacy and digital practices in a professional graduate program in Language and Technology to explore what and why students and teachers write in courses that use new information and communication technologies. Participants' writing practices using Facebook as a learning platform were discussed under the light of social literacy and academic literacies (Lea \& Street, 1998; Lillis \& Scott, 2007) approaches. The data show that writing teachers did not emphasize writing as social process and participants' writing is hybrid as it combines traces of genres that circulate on Facebook and in school. 
Similarly, Lopes and Castro investigate how students of an academic reading and writing course interact in an online scientific event. Bakhtinian analysis of the data reveals utterances produced by interactants dialogue with authors and with the articles providing collaboration that brings about knowledge construction. These findings demonstrate the importance of approaching reading and writing classes in a real meaningful situation in which students can experience and understand the multiple social functions of language.

Bessa also takes a Bakhtinian approach and combines it with the approach of Swales to study how young researchers quote when writing research articles. The author identified the purposes for which writers made use of the quoted speech in 10 exemplars written by Languages and Linguistics master's students. Findings reveal that the way young researchers use quoted speech is influenced by the sections of the article and also by the personal manner those writers select and organize information in their texts.

Cerutti-Rizzatti and Dellagnelo discuss the challenges of education for authorship in the academic sphere. Using a historical-cultural approach, the researchers analyze data that has been produced by the research group 'Writing Culture and Schooling' of the Federal University of Santa Catarina. The authors point out three relevant challenges in education for authorship and argue for the expansion of individuals' cultural repertoire throughout their educational path as to produce or reinforce autonomy.

Also working with authorship, Alves and Moura discuss the topic in opposition to plagiarism. The study examines introductions of research articles produced by undergraduate students initiating their degree as to identify the presence of plagiarism versus authorship in the texts. The authors draw on the Bakhtinian notion of authorship and on Swales's CARS model for introduction. The analysis shows that writers plagiarized by not adopting for themselves the role of authors of their own discourse. It is suggested that the inexperience of students in academic writing and the unfamiliarity with the content of the articles contributed to the practice of plagiarism.
How academic writing tasks engage students in epistemic practices enculturating them into their disciplines is the subject of Marinkovich, Velásquez, Cordova's and Cid's qualitative study. They find that in the five different disciplines examined, two distinctive orientations guide assignments: a prescriptive approach uses instructional genres for students to display received knowledge while a formative approach uses genres closer to disciplinary practices for students to think more deeply and form new knowledge.

Colombo and Prior also consider how fully instructors invite students into the discursive practices of their disciplines. They find that teachers who recognize that reading and writing practices are complex are more likely to be inclusive in their social attitudes toward less skilled students, to include reading and writing in their instruction and support students in their literacy struggles. Other teachers who see literacy as simple, transferrable skills tend to think students should have mastered them prior to entering the university. These teachers offer less support and see it as up to the student to meet their expectations.

Another group of articles present various interventions on campuses and evaluate their success. Ferreira and Lousada describe initiatives in the implementation of the Academic Literacy Laboratory at the University of São Paulo, Brazil. The laboratory aims at assisting undergraduate and graduate students in the production of academic texts either in foreign (English and French) or native languages. One of the main goals of that initiative is to meet the demands of the internationalization of Brazilian universities.

Silva and Reinaldo describe another intervention, implementing an academic reading and writing course for Computer Science undergraduate students. The researchers made use of the Writing in the Disciplines approach. The authors investigated the perceptions of the students enrolled in that course. Results demonstrated that students recognize the importance of teaching writing using a disciplinary approach and writing as an activity that contributes to the appropriation of academic texts.

Moyano and Guidice use a Systemic Functional Linguistics approach to enact also a Writing in the 
Disciplines intervention. In particular, they examine the role and operations of negotiation between professional peers in the PROLEA program at the Universidad de Flores (UFLO), in Argentina. Subject area professors collaborate with language and literacy professors to develop reading and writing tasks within course curricula, to provide supports for students in those tasks, and to structure editing activities for students. This project has been developed over a number of years and represents a further development of the PRODEAC model developed by one of the authors at another university.

Waigandt, Noceti, and Zapata also describe a series of institutional initiatives at two colleges at the Universidad Nacional de Entre Ríos in Argentina. These initiatives have gradually led to greater integration of academic literacy skills and literacy development into technical engineering education.

The last cluster of articles come out of the ILEES project (Iniciativas de Lectura y Escritura en la Educación Superior en Latinoamérica) which has over the last several years been mapping and analyzing the emergence of writing initiatives and research. The project is described in greater detail in these articles. Tapia-Ladino et al., based on interviews with academic leaders from Argentina, Chile, Colombia, and Mexico, give a synoptic view of the historical emergence of writing and reading studies in Spanish Speaking Latin American Higher Education. The interviews reveal major events, underlying causes, theoretical foundations and disciplinary orientations that were part of this emergence. The interdisciplinary conjunctions from which the field has arisen have left the disciplinary identity still diffuse.

A parallel interview study of leading Brazilian writing scholars by Cristovão and Vieira identifies five writing centers in the country and the theoretical approach most mentioned. The interviews revealed the need for expansion, recognition and strengthening of higher education academic writing initiatives in Brazil.

Narváez-Cardona surveys publications to examine engineering writing programs in Spanish-speaking countries. The analysis of 22 publications suggests that initiatives in engineering are recent (as of 2009) and publications tend to be pedagogically-oriented.. The trends suggest that the Latin-American writing advocates in engineering might broaden research scope.

Finally the three book reviews give a sense of recent work now coming from the region. One review by Vanessa Arlésia Souza Ferretti Soares focuses on work coming from Brazil; another by Guillermo Cordero Carpio and Monica Prior focus on work from Colombia. And the third, by Olga Lopez, considers books from other Spanish-speaking countries.

We hope this representation of the developing work on writing from the Central and South American region contributes to the next stage of work and to even greater and more regular professional communication on the subject. 